\title{
Simultaneous drainage events from supraglacial lakes on the southern Inylchek Glacier, Central Asia
}

\section{Article}

Cite this article: Sakurai N, Narama C, Daiyrov M, Esenamanov M, Usekov Z, Inoue H (2022). Simultaneous drainage events from supraglacial lakes on the southern Inylchek Glacier, Central Asia. Journal of Glaciology $\mathbf{6 8}$ (268), 209-220. https://doi.org/10.1017/ jog. 2021.77

Received: 20 November 2020

Revised: 7 June 2021

Accepted: 8 June 2021

First published online: 26 July 2021

\section{Key words:}

Debris-covered glaciers; glacier discharge; glacier hazards; glacier hydrology

\section{Author for correspondence:}

Naoki Sakurai,

E-mail: n.sakurai1001@gmail.com;

Chiyuki Narama,

E-mail: narama@env.sc.niigata-u.ac.jp
Naoki Sakurai ${ }^{1}$, Chiyuki Narama ${ }^{2}$, Mirlan Daiyrov ${ }^{3}$, Muhammed Esenamanov ${ }^{3}$, Zarylbek Usekov ${ }^{3}$ and Hiroshi Inoue ${ }^{4}$

${ }^{1}$ Niigata University, Graduate School of Science and Technology, Niigata, Japan; ${ }^{2}$ Niigata University, Program of Field Environmental Research, Niigata, Japan; ${ }^{3}$ Central Asian Institute for Applied Geosciences (CAIAG), Bishkek, Kyrgyzstan and ${ }^{4}$ National Research Institute for Earth Science and Disaster Resilience (NIED), Tsukuba, Japan

\section{Abstract}

To understand the mechanism of simultaneous drainage event related to supraglacial lakes on a debris-covered glacier, we investigated water-level variations of supraglacial lakes on the southern Inylchek Glacier in Kyrgyzstan. To examine these variations, we used daily aerial images for 2017-2019 from an uncrewed aerial vehicle that were converted to $15 \mathrm{~cm}$-digital surface models and ortho-images. Our main results are as follows: (1) When one lake drained, the water levels of other lakes simultaneously increased, indicating that drainage water is shared with several lakes through a main englacial conduit. In one drainage event, a branched off englacial conduit clearly connected to a main englacial conduit. (2) Sometimes several lakes discharged simultaneously, indicating that several lakes had connected to a main englacial conduit that had opened. Such cases can cause larger-scale drainage than that from the opening of a branched off englacial conduit. (3) Simultaneous drainage occurred twice in the same year, each time through a different conduit, indicating that the main englacial conduit can be abandoned and reused. (4) In some lakes, the water level on the hydraulic gradient line increased gradually with nearly the same increase rate just before drainage. Such an increase may be an indicator of a possible simultaneous drainage event.

\section{Introduction}

In Asian mountain regions, large-volume drainage events occur from supraglacial lakes on debris-covered glaciers. For example, during May-June 2008, the Hunza Valley of the Karakoram had four large drainage events from supraglacial lakes at the terminus of the Ghulkin Glacier. These drainages destroyed homes and four irrigation channels in Borit Village and also temporarily closed the Karakoram Highway (Richardson and others, 2009). On 29 April 2009, in the Lunana region of northwestern Bhutan, a sudden large discharge event occurred through englacial or subglacial conduits at the Tshojo Glacier, forcing the evacuation of the people of Punakha Town, located $70 \mathrm{~km}$ downstream (Komori and others, 2012). After this event, Yamanokuchi and others (2011) observed a large outlet of an englacial conduit through which drainage water flowed at the glacier terminus. Thus, the drainage was considered to have been supplied by water that was stored in the supraglacial lake as well as in the englacial or subglacial conduits (Komori and others, 2012). Later, on 12 July 2016, the Lhotse Glacier in the Khumbu region of eastern Nepal had large-scale drainage from a large supraglacial lake and englacial storage water (Rounce and others, 2017). Lastly, from April to July 2017, a supraglacial lake with an area of $180000 \mathrm{~m}^{2}$ rapidly formed on a tributary of the Khumbu Glacier, then completely discharged in mid-July (Miles and others, 2018a). These recent studies show that large-scale drainage events are coupled with supraglacial and englacial water-storage dynamics.

Supraglacial lakes on debris-covered glaciers form by water flowing into a basin or depression through englacial or surface channels. They form when the englacial conduits close and then continue to develop until a connecting englacial conduit opens (Benn and others, 2017; Narama and others, 2017). For example, a lake may form due to closing of englacial channels by roof collapse, creep closure, freezing of stored water and deposition of ice and debris (Gulley and Benn, 2017; Narama and others, 2018). Then, the lake may expand by erosion of the lake basin and englacial channel due to ice melting, inflow of ice meltwater and transfer of lake water through lake connectivity to the englacial network (Sakai, 2001; Benn and others, 2012; Miles and others, 2017a; Narama and others, 2017; Watson and others, 2017). In addition, the development of supraglacial lakes depends on the glacier's surface gradient (Reynolds, 2000; Liu and others, 2015), ice velocity (Miles and others, 2017a) and the glacier mass balance (Benn and others, 2012). Conversely, any water from the surface and side of the glacier that fills a subglacial reservoir will affect the motion at the glacier bed (Bartholomaus and others, 2011). Moreover, supraglacial lakes accelerate glacier ablation due to their greater absorption of solar radiation as well as circulation of meltwater (Sakai, 2001; Benn and others, 2012; Thompson and others, 2012; Miles and others, 2018b), particularly those with high turbidity water (Takeuchi and others, 2012). 
Satellite data showed that the total ponded area of some debris-covered glaciers changed seasonally during 2000-2015 in the Everest region (Watson and others, 2016). Also, during 2010, 2012 and 2015, each supraglacial lake on Ngozumpa Glacier had a different life cycle of drainage and recharge (Benn and others, 2017). In central Tien Shan, the number of supraglacial lakes on the Southern Inylchek changes seasonally, as it also does on the Tomur Glacier, but the timing of their maxima differs despite being in the same climate region (Narama and others, 2017).

In the Langtang Valley of central Nepal, supraglacial lakes expand in the pre-monsoon period due to snow melt, and then shrink due to the opening of englacial conduits that occur from increasing precipitation and snow-ice melting in the monsoon period (Miles and others, 2017a). In the study area of the southern Inylchek Glacier, the Tien Shan, satellite data in 1999-2015 show the number of supraglacial lakes to vary seasonally. This number increases in April, reaches a maximum from May to June, and then decreases from June to July (Narama and others, 2017). The increase in number from April to June is caused by melt, and the later decrease in number is caused by connections of the supraglacial lakes to the englacial conduit network. Daily variations of water levels have been measured in supraglacial lakes using water-level loggers (Miles and others, 2017b; Narama and others, 2017); the connectivity and relationship between supraglacial lakes and englacial conduits remain unclear.

The large-volume drainage events of supraglacial lakes can occur on any debris-covered glacier. Large-scale flooding might be caused by drainage from a single large supraglacial lake, or from a simultaneous drainage event involving multiple glacial lakes (Narama and others, 2017). Although such simultaneous drainage events have been studied, we still need a better understanding of their mechanism, their precursor phenomenon, the possibility of recurrence and the scale of the englacial network. In this study, we focus on supraglacial lakes on the southern Inylchek Glacier in Kyrgyzstan.

To help understand the mechanism for simultaneous drainage, we obtained spatial data on daily water levels to determine the relationship between the lake-level changes of a given supraglacial lake and its network connectivity. Specifically, we investigated daily water-level variations of the lakes in the summers of 2017, 2018 and 2019, primarily using digital surface models (DSMs) and ortho-images derived from an uncrewed aerial vehicle (UAV). In describing the network, we make the distinction here between an 'englacial conduit' as a conduit covered on all sides by ice or debris, and a 'supraglacial conduit' as a conduit partly exposed on the surface.

\section{Study area}

The study area is the southern Inylchek Glacier in the central Tien Shan mountains (Fig. 1). This glacier is the largest in Kyrgyzstan $\left(\sim 500 \mathrm{~km}^{2}\right.$ in area, $60.5 \mathrm{~km}$ long), with a debris-covered zone that stretches over $22 \mathrm{~km}$ up-glacier from the glacier terminus (Shangguan and others, 2015; Narama and others, 2017), and medial moraines from several tributary glaciers. For 1999-2007, the average annual mass balance was $-0.28 \pm 0.46 \mathrm{~m}$ w.e. $\mathrm{a}^{-1}$ (Shangguan and others, 2015). The estimated maximum thickness is $380 \mathrm{~m}$, and the mean thickness of its debris-covered part is $136 \mathrm{~m}$ (Pieczonka and others, 2018). Partway down the glacier, and between it and the northern Inylchek Glacier, lies Lake Merzbacher (Fig. 1). The surface-flow velocities up-glacier of this lake are faster than those down-glacier (Nobakht and others, 2014; Shangguan and others, 2015). Distributed on its debriscovered area lie many supraglacial lakes that have an annual seasonal drainage cycle (Narama and others, 2017).
The closest meteorological stations are the Tien Shan Station $\left(78.2^{\circ} \mathrm{E}, 41.9^{\circ} \mathrm{N}, 3614 \mathrm{~m}\right.$ a.s.l., data from 1960 to 1997$)$ and the Koilu Station $\left(79.0^{\circ} \mathrm{E}, 42.2^{\circ} \mathrm{N}, 2800 \mathrm{~m}\right.$ a.s.l., data from 1960 to 1990; Fig. 1), with annual precipitation amounts of 279 and $311 \mathrm{~mm} \mathrm{a}^{-1}$, respectively (Reyers and others, 2013). About $75 \%$ of the annual precipitation occurs from March to September with peak precipitation occurring in June-July. According to observation data at the Tien Shan station, the annual average air temperature is $-7.7^{\circ} \mathrm{C}$, with the lowest monthly average temperature being $-21.8^{\circ} \mathrm{C}$ in January, the highest being $4.3^{\circ} \mathrm{C}$ in July (Osmonov and others, 2013; Shangguan and others, 2015).

\section{Methods}

\subsection{Field survey}

We ran a field survey on the middle part of the southern Inylchek Glacier near the Lake Merzbacher B.C. during summers in 2017, 2018 and 2019. The camp was built by the Central-Asian Institute for Applied Geosciences (CAIAG) and Deutsches GeoForschungsZentrum (GFZ) (Fig. 1). Aerial photographs were taken using a UAV (Phantom-3 Advance and Phantom-4 (DJI): camera pixels $12.4 \mathrm{MP}$, lens FOV9⿺辶, $20 \mathrm{~mm}, \mathrm{f} / 2.8$, ISO 100-1600) each day (22 July-15 August 2017, 8-29 July 2018, and 12-19 July 2019) to determine the supraglacial lakes' waterlevel variations. The area of the UAV survey was $2 \times 2 \mathrm{~km}^{2}$ in 2017 and $2 \times 2.5 \mathrm{~km}^{2}$ in $2018-2019$. The photo forward lap and side lap were 80 and $65 \%$, respectively. The survey time was 05:30-07:00 am (UTC +6), as this time period had the clearest weather as well as good sun angle for photographs. We changed the flight time on several days due to the weather.

To correct the relative water-level fluctuations to absolute elevation values, we also made ortho-images and DSMs using GCPs (ground control points). The GCPs in 2017 (Fig. 2a), in 2018 (Fig. 2b) and in 2019 (Fig. 2c) were measured by a GNSS survey for $30 \mathrm{~min}$ with Trimble GeoExplorer6000. We obtained absolute positions with $20-40 \mathrm{~cm}$ accuracy at the GCP positions and lakelevel data by post-processing with data from the Kyrgyz GNSS reference stations. We also set up water-level data loggers (water pressure transducer HOBO U20) based on pressure measurements in the water (water pressure) and at the nearby shore (barometric pressure). The water levels were determined every hour by correcting water pressure data with barometric pressure data. We also set up time-lapse cameras (Brinto) for $1 \mathrm{~d}$ intervals from 2016 to 2019 (Fig. 2).

\subsection{GIS analysis}

Ortho-images and DSMs come from UAV aerial images (resolution: $15 \mathrm{~cm}$ ) via the Pix4D mapper of SfM (Structure from Motion) software. Briefly, images with GNSS locations from the UAV are imported into the SfM software, and the software automatically creates the DSM and ortho-images. (For details, see Immerzeel and others (2014) and Piermattei and others (2015, 2016).) Daily water levels are derived from these UAV DSMs and ortho-images. We also created ortho-images and DSMs using the GCPs setting of Trimble GeoExplorer6000. GCP DSMs are used to relate relative water-level variations to absolute elevation. We numbered the lakes from the UAV survey then used the following procedure to acquire the water levels.

(1) For each lake, designate a 'standard' data from the DSM and ortho-image from when that lake level was relatively low. For example, for lake 1 in 2017, the standard data are on 25 July 2017, but for lake 4 in 2017, the standard data are on a different day. 


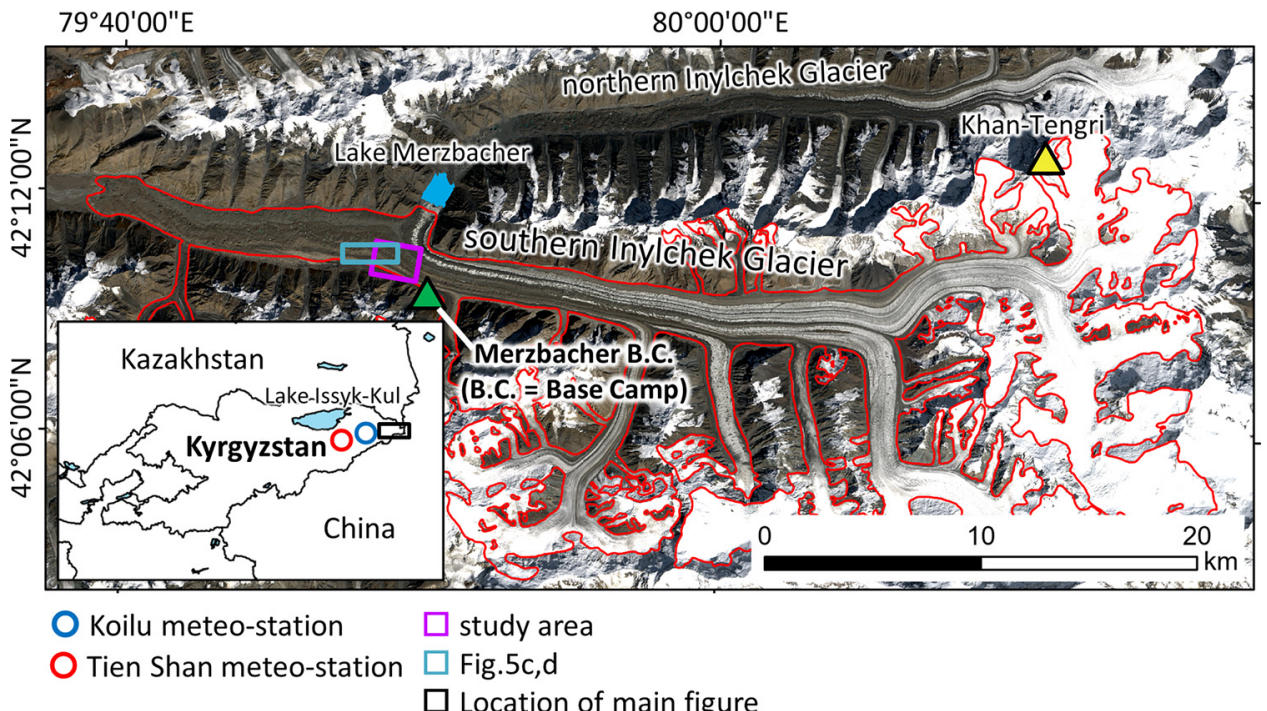

Fig. 1. The southern Inylchek Glacier in central Tien Shan, Kyrgyzstan (black box region in inset map). The glacier outline (red) is adapted from the GAMDAM glacier inventory (Sakai and others, 2015). The purple box is the study site shown in Figure 2. Image is Landsat-8/OLI taken on 4 September 2017.
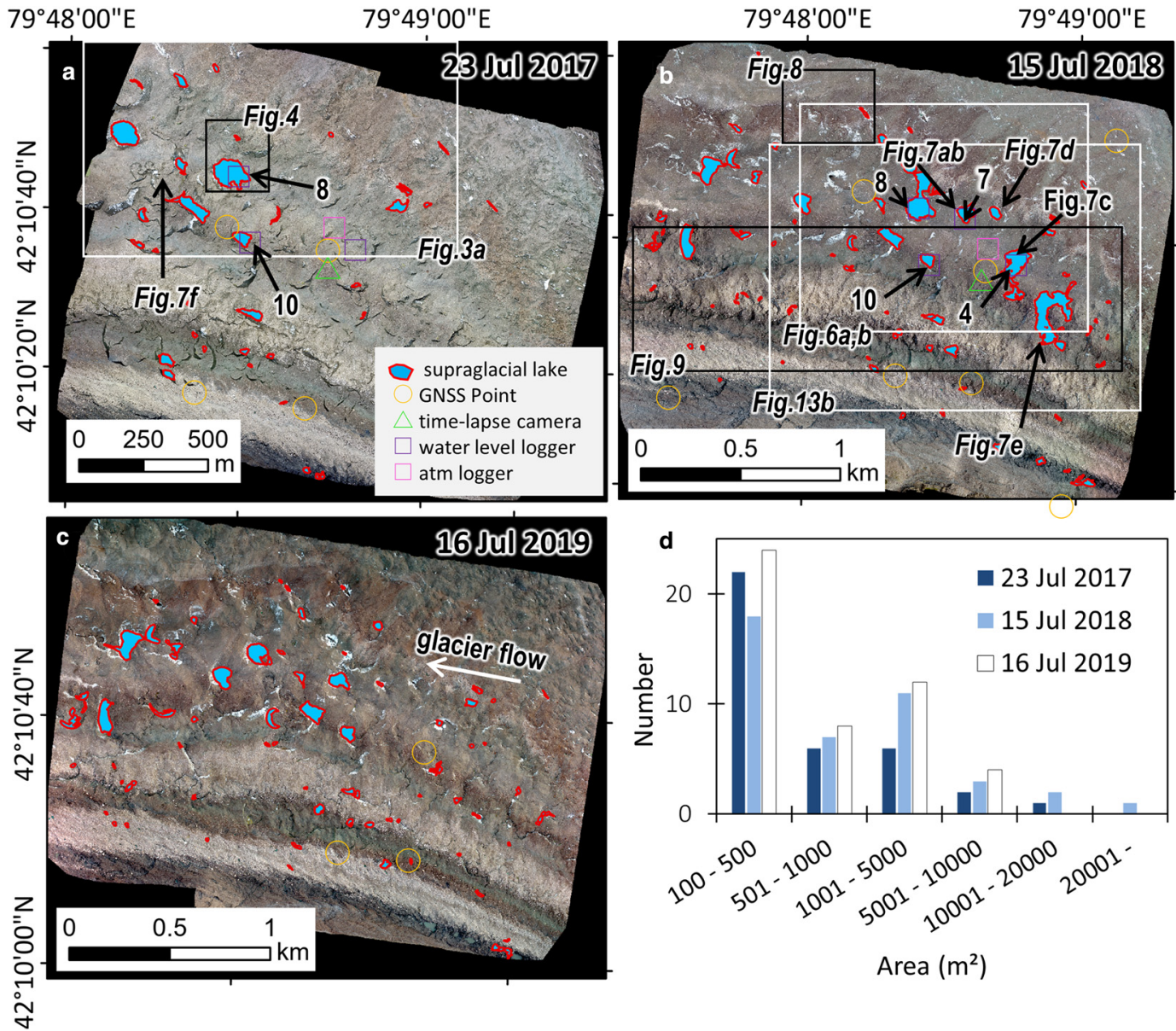

Fig. 2. Study area imaged by UAV (purple box in Fig. 1). (a) The study area in $2017\left(2 \times 2 \mathrm{~km}^{2}\right)$. (b) Same as (a) except 2018 and larger area ( $\left.2 \times 2.5 \mathrm{~km}{ }^{2}\right)$. (c) Same as (b) except for 2019. Regions shown in subsequent figures outlined with black and white boxes and labeled. (d) Lake area distribution in the study area on the dates shown.

(2) As the glacier surface here flows at a speed of $\sim 4 \mathrm{~m}$ per month, all other ortho-images are fitted to the standard ortho-image and DSM for each lake by shifting them using the 'georeference' function (non-linear) with more than ten tie points in ArcGIS. The shift is horizontal because the surface gradient is $<2^{\circ}$ in the study site $(2 \times 2.5 \mathrm{~km})$.
(3) Manually make lake polygons for each day using each shifted ortho-image during survey period. Then, convert the perimeter lines of the lake polygon to points at $15 \mathrm{~cm}$ intervals and extract relative water-level elevations of point data of the perimeter line from each lake's 'standard DSM'. The relative water-level elevation is from the average elevations of these 
a

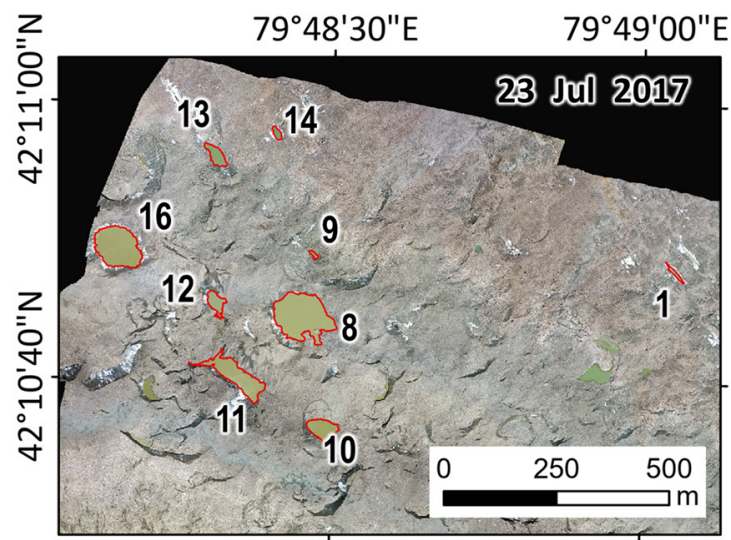

b

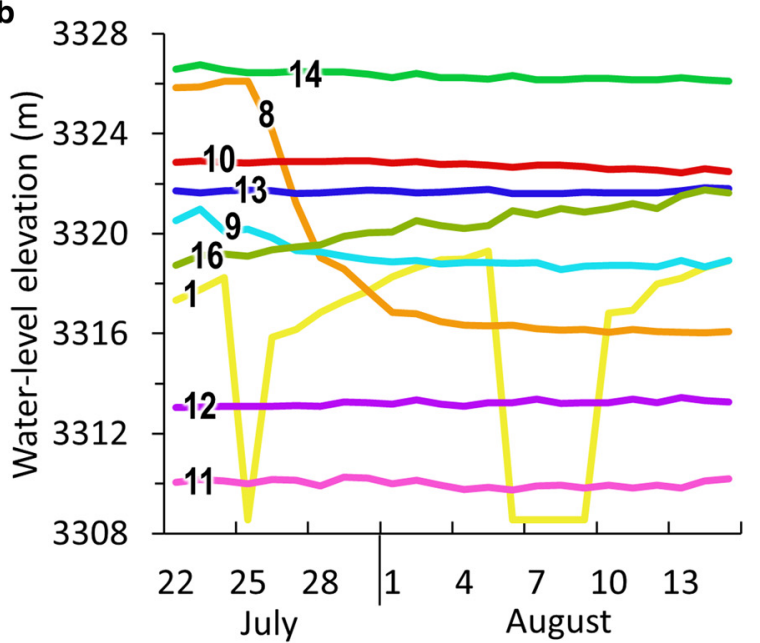

Fig. 3. Lake locations and water-level variations from July to August 2017. (a) Location of lakes with ID numbers. Region is the white rectangle in Figure 2a. The ortho-image was made from UAV data on 23 July 2017. (b) Daily water-level variations (based on DSM data) for the numbered lakes in (a).

points (over 500 points), excluding $45 \%$ of the highest and lowest values, on the lake's 'standard' DSM. Water volume changes are calculated based on the standard DSM using the 'Cut-Fill' function in ArcGIS. Finally, convert relative-elevation changes of water level to absolute elevation using DSM based on GCPs from Trimble GNSS data.

A UAV was used because it allowed us to discern daily waterlevel variations when compared to $15 \mathrm{~cm}$ DSMs and ortho-images. However, UAVs limit the survey range and survey period, and require good weather. In addition to these limitations, a UAV's battery requires charging, limiting potential sites to places where electric power can be supplied.

To investigate simultaneous drainage events in May and July, we used 13 satellite images of Landsat-8/OLI, Sentinel-2 and PlanetScope satellite images in 2017-2019. Supplementary Table 2 summarizes the drainage events and data material in 2017-2019. Lake-area variations outside the UAV survey period were determined from 13 satellite data and their outlines manually delineated on false-color images as in (3) above.

\subsection{Accuracy of water-level variation}

Water-level data taken from UAV ortho-images and DSMs were tested against direct measurements from water-level loggers (Hobo U20; accurate to $\pm 1.5 \mathrm{~cm}$ ). These water-level logger measurements came from lakes 8 and 10 in 2017, lakes 4, 7 and 8 in 2018. Supplementary Table 1 shows the direct measurements minus the UAV-DSM values. The average difference of five lakes was $6.3 \pm 8.8 \mathrm{~cm}$. These uncertainties are significantly less than the lake-level variations that could vary up to $20 \mathrm{~m}$.

\section{Results}

\subsection{Number and distribution of supraglacial lakes in mid-July 2017-2019}

Figures 2a-c show UAV ortho-images in mid-July 2017, 2018 and 2019. Locations of the supraglacial lakes, shown in blue with red outline, are similar in all 3 years. All lakes had high turbidity. Counting only those of area over $100 \mathrm{~m}^{2}$, the total numbers of lakes in the figure images (within the same overlapping area) are 37 on 23 July 2017, 42 on 15 July 2018 and 48 on 16 July 2019. For those over $1000 \mathrm{~m}^{2}$, the total numbers are 9 in 2017 , 17 in 2018 and 16 in 2019. For the lakes over $5000 \mathrm{~m}^{2}$, the totals for these years are even smaller, at 3, 6 and 4, respectively. These larger lakes lie near the middle, along the glacier flow direction. The number of lakes in all size classes is plotted in Figure $2 \mathrm{~d}$. The total number of lakes is generally larger in 2018 and 2019 than in 2017.

\subsection{Storage and drainage phenomena}

\subsubsection{Drainage event in July 2017}

Within the area of Figure $3 \mathrm{a}$, the water levels of nine lakes $(1,8-$ 14, 16) vary during 22 July to 15 August 2017 as plotted in Figure 3b. For example, initially near $3326 \mathrm{~m}$, the water level of the largest, lake 8 , first increases slightly by $0.3 \mathrm{~m}$ through 25 July, a volume increase of $2723 \mathrm{~m}^{3}$, then drops sharply by $9.8 \mathrm{~m}$ by 4 August, a volume loss of $62293 \mathrm{~m}^{3}$, and thereafter did not change. Nearby, the much smaller lake 9 drops $2 \mathrm{~m}$ (volume loss: $328 \mathrm{~m}^{3}$ ) from 24 July to 30 July, thereafter remaining at the same level $(\sim 3319 \mathrm{~m})$. Before-and-after ortho-images in Figure 4 (25 and 26 July 2017) show the changes in surface conditions from the drainage of these lakes. The two lake areas clearly shrink after drainage and ice-exposed parts become visible in Figure $4 \mathrm{~b}$ due to erosion by the drainage water flowing from lake 8. During the field survey, we observed a conduit with ice-exposed parts on the glacier surface between the two lakes.

Lake 1 discharges twice during the $25 \mathrm{~d}$ observation period (Fig. 3b). Specifically, the water level declines $9.9 \mathrm{~m}$, draining $1378 \mathrm{~m}^{3}$ on 24 July, then the water level increases by $7.5 \mathrm{~m}$ the next day, a volume of $738 \mathrm{~m}^{3}$, and then an even larger drainage of $1756 \mathrm{~m}^{3}$ occurs on 5 August in which the water level drops $10.7 \mathrm{~m}$. Four days later, the lake recharges, gaining $942 \mathrm{~m}^{3}$ over $1 \mathrm{~d}$ as its water level increases $8.3 \mathrm{~m}$. These three lakes $(1,8,9)$ gradually increase just before drainage. Similarly, the water level of lake 16 increases gradually, but does not drain during the survey period (Fig. $3 \mathrm{~b}$ ). The water levels of the remaining lakes (10, $11,12,13,14)$ remain relatively stable during the survey period with two of them $(10,11)$ not draining completely during at least 2 years of observation.

\subsubsection{Drainage events in May and July 2018}

Figure 5a shows water-level (thick line) and temperature (thin line) variations based on water-level data loggers from May through July 2018 for four lakes (see Supplementary Table 1). The temperature remained $\sim 1-2^{\circ} \mathrm{C}$ from the time that water level starts rising above the data logger. But the temperature fluctuates more when the lake is shallower due to drainage from lake. Lake 10 discharged at 1:00 on 7 May, followed by lake 8 at 5:00 on 13 May. Later, lakes 4, 7 and 8 simultaneously discharge on 17 July. The images in Figure 5b show the drainage of lake 4 between 12 and 13 May showing that this lake drained at about the same 

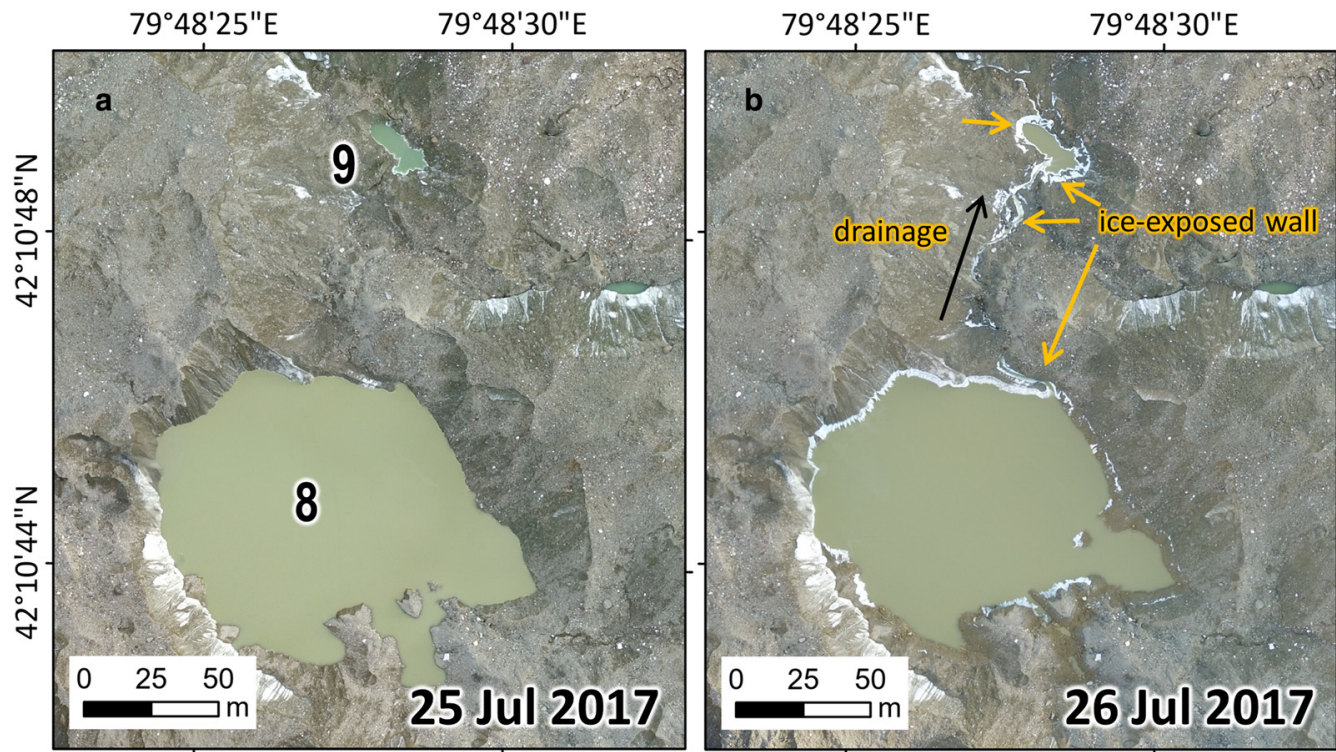

Fig. 4. UAV ortho-images of lakes 8 and 9 before and after drainage. Yellow arrows show an ice wall along the englacial conduit that was exposed after drainage. Black arrow shows drainage direction. Region is the black rectangle in Figure 2a.
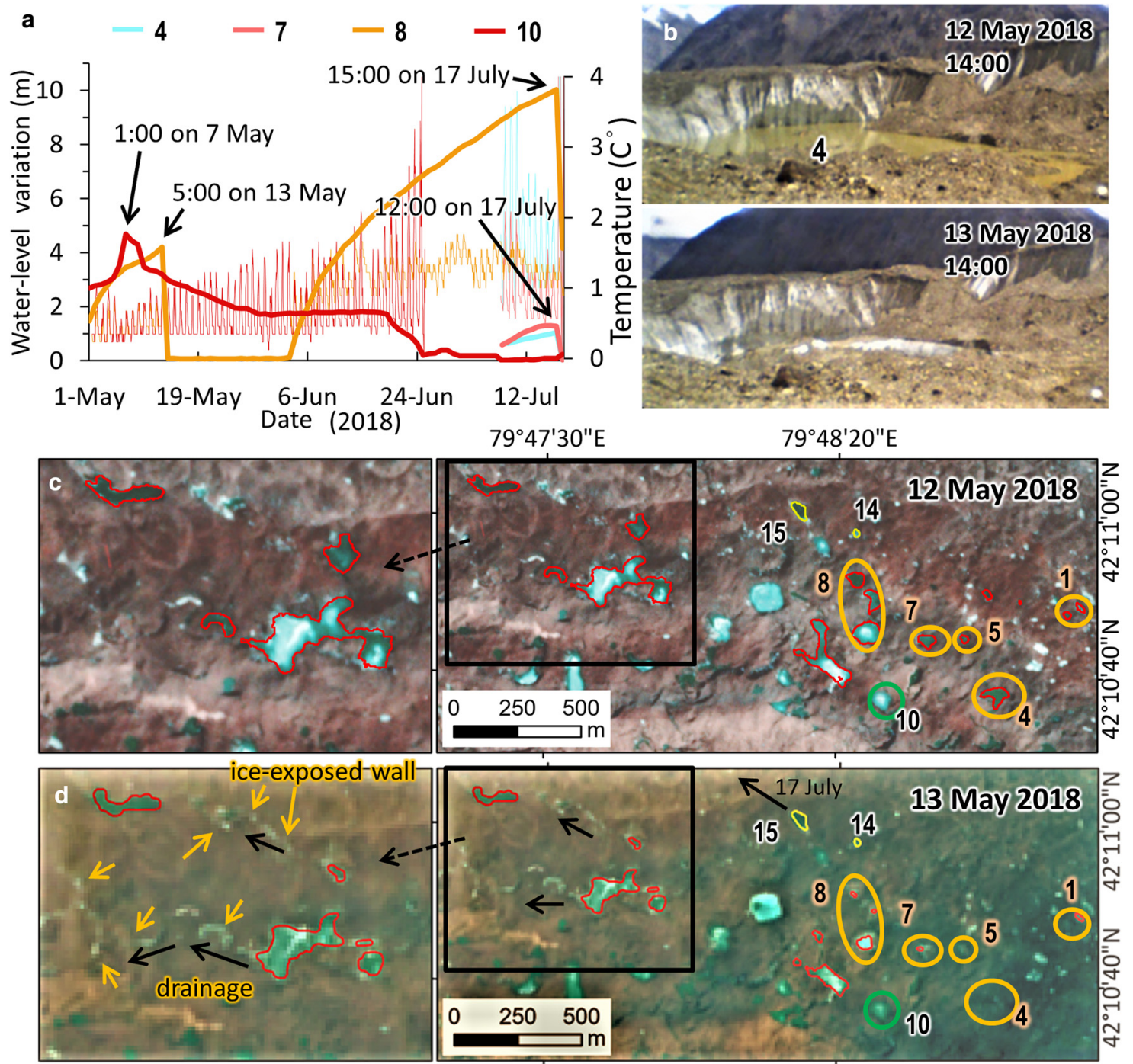

Fig. 5. Drainage event on 13 May 2018. (a) Water-level (thick line) and temperature (thin line) variations of four lakes from water-level logger data. (b) Sequential images of lake 4 that discharged on 12-13 May. (c, d) PlanetScope and Sentinel-2 images taken on 12 and 13 May. Region is the blue rectangle in Figure 1. Left images are enlargements of the black box in the right images. Yellow circles show lakes in the simultaneous drainage event. Yellow arrows show ice wall along englacial conduit that was exposed after drainage. Black, solid arrows show drainage direction (with drainage date in d, right side). All times shown are local (GTM $+9: 00)$. 
$79^{\circ} 48^{\prime} 00^{\prime \prime} \mathrm{E}$
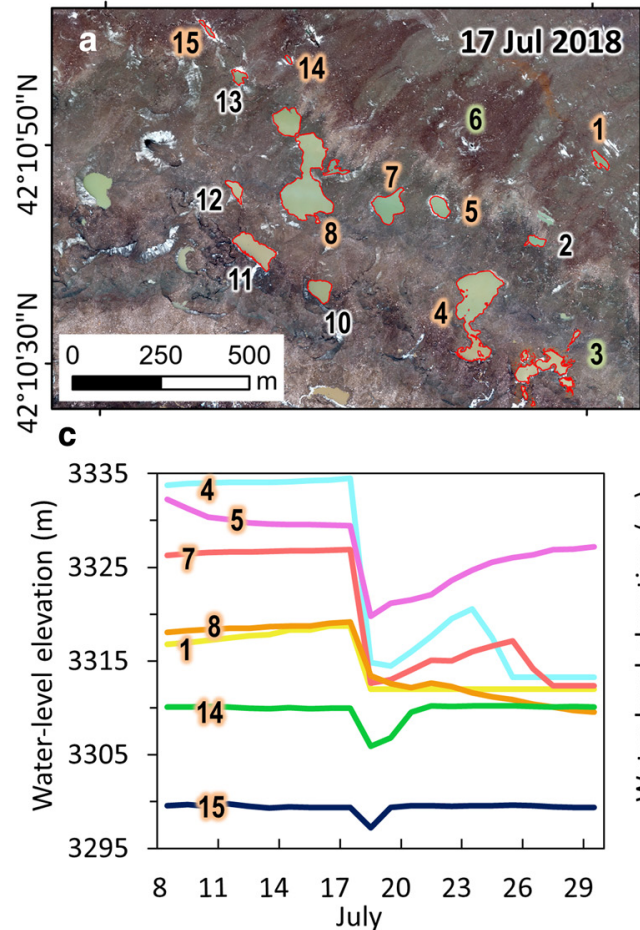

$79^{\circ} 48^{\prime} 00^{\prime \prime} \mathrm{E}$

$79^{\circ} 49^{\prime} 00^{\prime \prime} \mathrm{E}$
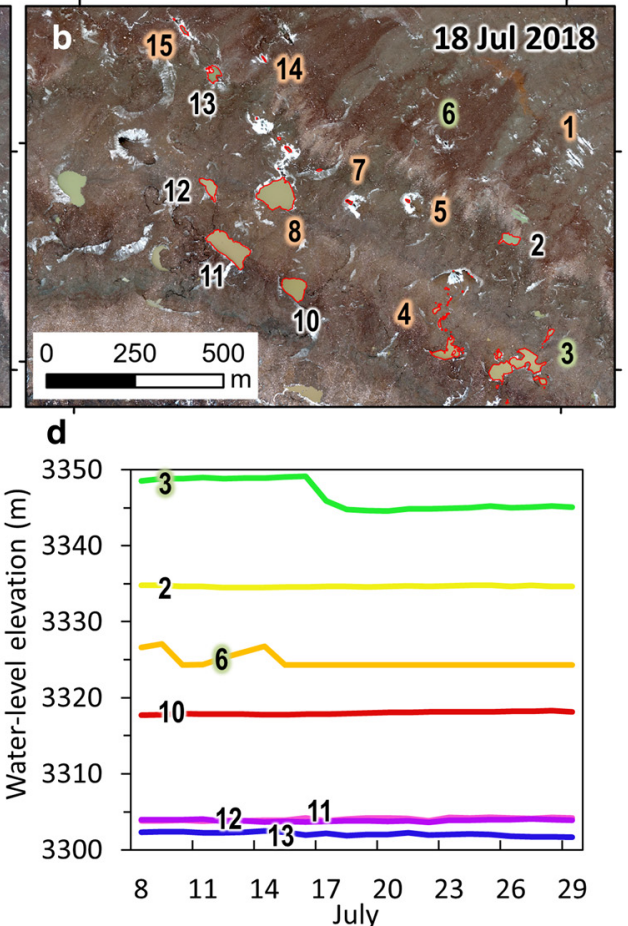

Fig. 6. Lake locations and water-level variations in July 2018. (a) Location of lakes with ID numbers on 17 July. Region is the white rectangle in Figure 2 b. IDs with orange highlight are lakes that drained simultaneously, IDs with white highlight are lakes unaffected by the multi-lake drainage event. IDs with green highlight are lakes that drained on another day. The ortho-image was made from UAV data on 17 July. (b) Same as (a) except the next day. (c) Daily water-level variations (based on DSM data) in lakes that simultaneously drained. Lake 8 includes former lake 9 of 2017 due to a merging of the lakes prior to this image. (d) Same as (c) except for the lakes that did not simultaneously drain.
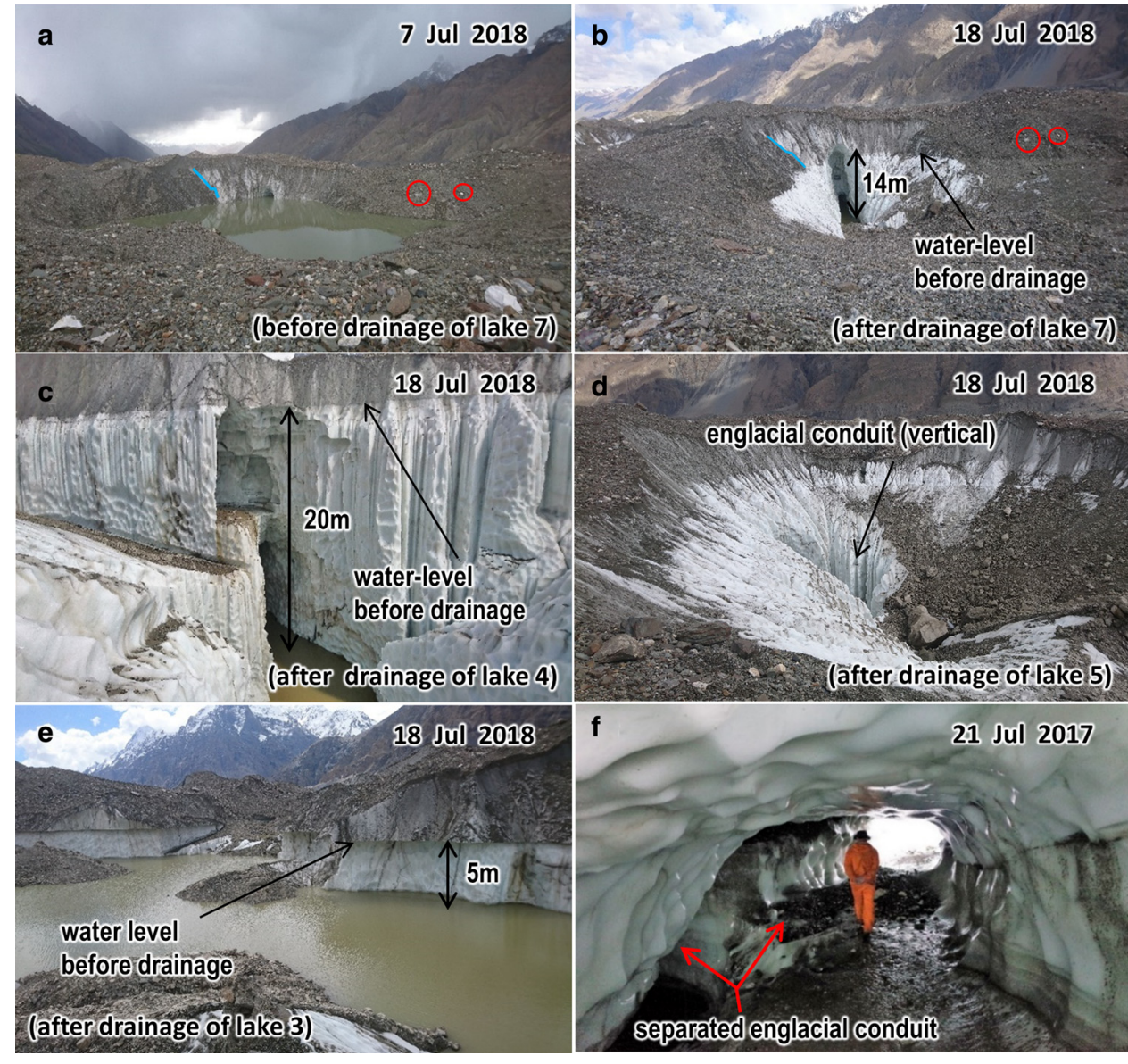

Fig. 7. Field photos near several lakes. (a, b) Lake 7 before and after drainage on 17 July 2018. Red circles show landmark stones. (c) Lake 4 after drainage on 17 July 2018. (d) Lake 5 after drainage on 17 July 2018. (e) Lake 3 situation after drainage on 16 July 2018. (f) Separated englacial conduit at the location marked in Figure 2a. 

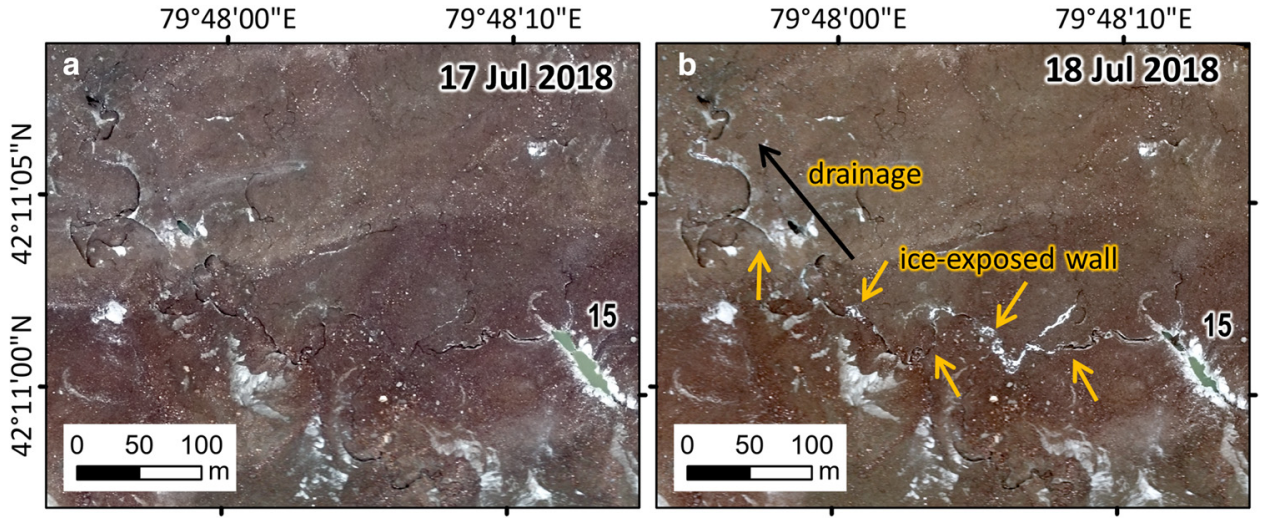

Fig. 8. Drainage of lake 15 on 17 July 2018. Drainage route is marked by the black arrow and exposed ice wall is marked by yellow arrows in (b). New white areas in (b) show newly exposed ice. Ortho-images ( $a, b)$ were made from UAV data on 17 and 18 July 2018. Location is marked in Figure $2 b$.

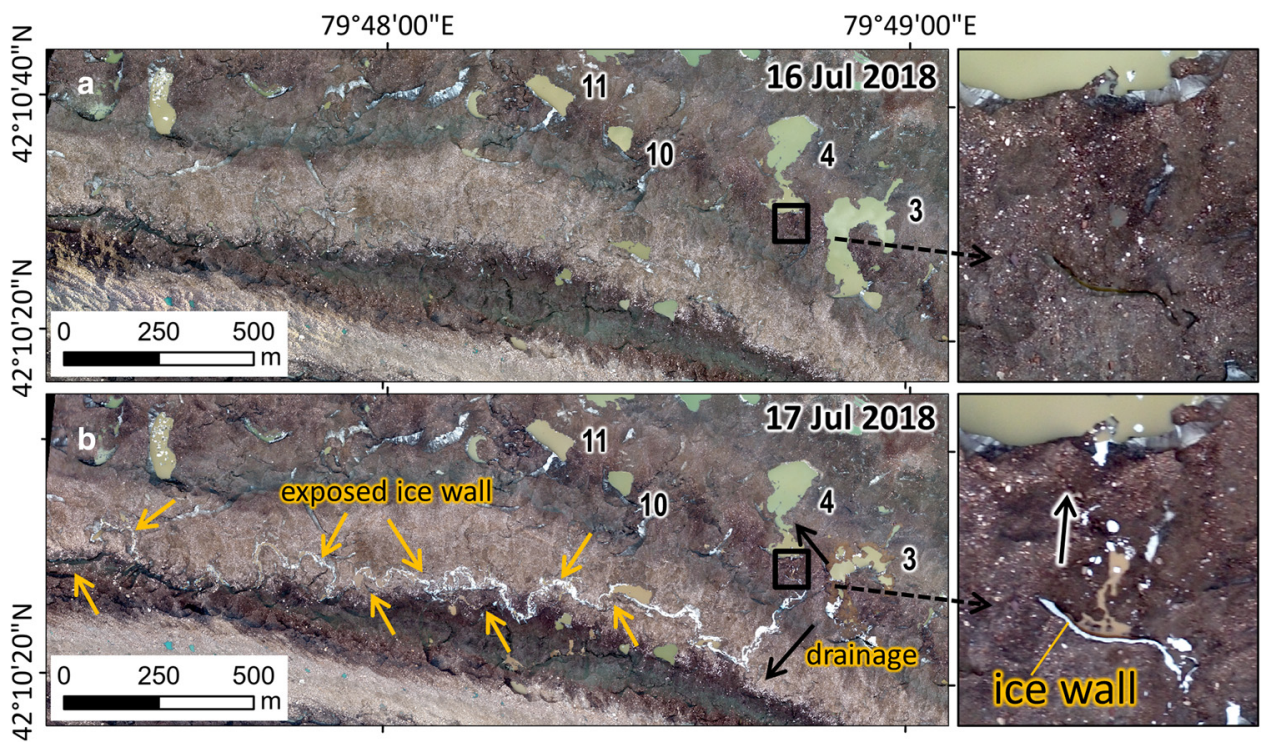

Fig. 9. Drainage of lake 3 on 16 July 2018. Newly exposed ice occurs in (b) along the englacial conduit with some parts exposed on the surface due to debris washed away during the drainage. Black arrows show water-flow directions. Some lake water flowed to lake 4 . Seven lakes drained the next day. Right box shows close-up of inset region. Yellow arrows show exposed ice along englacial conduit where most water flowed. Ortho-images (a, b) were made from UAV data on 16 and 17 July 2018. Location is marked in Figure 2b.

time as that of lake 8. Additional PlanetScope and Sentinel2 images in Figures $5 c$, d show the drainage of lakes labeled with orange highlighting $(1,4,5,7,8)$ on $12-13$ May (Supplementary Table 2). The black rectangles of Figure 5d show newly exposed ice on 13 May, indicating two drainage routes for this event. Thus, these results show simultaneous drainage events from several lakes within an area of $1 \mathrm{~km}^{2}$ on $12-13$ May and 17-18 July.

For July 2018, we examined the 14 lakes marked in Figure 6. The seven lakes labeled with orange highlighting in Figures $6 a, b$ $(1,4,5,7,8,14,15)$ simultaneously discharge on 17-18 July (Fig. 6c). From Figure 5a, lakes 4, 7 and 8 drain at about 12:0015:00 on 17 July. In calculating the amount of lake water simultaneously discharged (based on the DSMs), we find a total amount of $188673 \mathrm{~m}^{3}$. Even without the additional water in the englacial channel, this is a large transference of water in $1 \mathrm{~d}$. In contrast, the lakes highlighted in white $(2,10-13)$ do not change during this period in July, whereas those highlighted in green $(3,6)$ changed, but not during the simultaneous drainage event (Fig. 6d).

We now examine the cases of lakes $3-5$ and 7 . For lake 7 , the water level drops $\sim 14 \mathrm{~m}$ during the 17 July drainage event (Figs $7 \mathrm{a}, \mathrm{b}$ ). For lake 4, the images in Figure $7 \mathrm{c}$ show a $20 \mathrm{~m}$ drop, and during our survey, we found a large englacial conduit after drainage. For lake 5, Figure $7 \mathrm{~d}$ shows a large, vertically oriented englacial conduit that was exposed after drainage on 18 July. Lake 3 drained a day earlier, showing a drop of $\sim 5 \mathrm{~m}$ (Fig. 7e). From 8 to 17 July, before the drainage event, the water levels of lakes $1,4,7$ and 8 gradually increased by $0.6-2$ $\mathrm{m}$. In contrast, the level of lake 5 decreased gradually by $2.5 \mathrm{~m}$ (losing $7999 \mathrm{~m}^{3}$ ) during 8-12 July and then maintained the same level before drainage on 17 July. Then, after the drainage event, lakes 4,5 and 7 recharged, with two of them $(4,7)$ discharging again $(23,25$ July). According to the analysis of PlanetScope satellite images, lake 5 also discharged again, but on a later date (7-9 August; Supplementary Table 2).

Of the seven lakes that drained on 17 July, five $(1,4,5,7,8)$ also drained on 13 May. The two lakes $(14,15)$ did not discharge on 13 May, with both recharging to within $0.2 \mathrm{~m}$ of their predrainage water level within $3 \mathrm{~d}$ (Fig. 6c). These two lakes have the lowest elevations of all seven lakes in the event. This result suggests that the drainage path re-routed toward lakes 14 and 15 after the 13 May drainage event. For the drainage on 17 July, the water flowed through a complex mixture of englacial and supraglacial conduit. For instance, in the case of lake 15, 

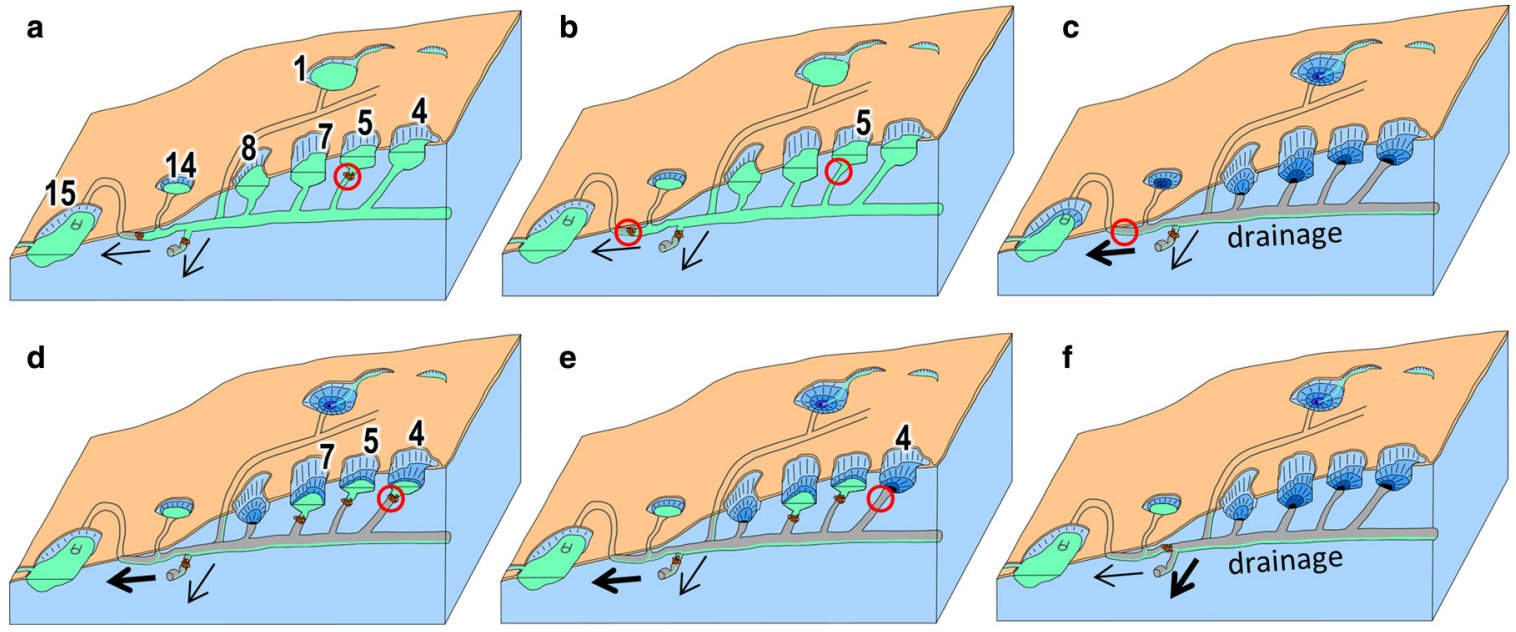

Fig. 10. Estimated englacial network changes in the study site. (a) Distribution of lakes and englacial conduits. (b) First, lake 5 drains due to a newly opened connection between its branch and the main englacial conduit. (c) Simultaneous drainage of lakes due to opening of the main englacial conduit. (d) Recharging of each lake due to closure of the branch englacial conduits by debris and ice. (e) Re-discharge of each lake due to opening of a branch englacial conduit. (f) Simultaneous drainage occurs due to the opening of another route of the main englacial conduit.

Figure 8 shows ice walls that were exposed on the surface due to drainage water on 17 July. The position of the exposed ice walls changed between May and July (Figs 5, 8). This change indicates that the drainage route changed between May and July.

Of the lakes that did not respond to the drainage event on 17 July, the five with white highlight in Figs $6 a, b(2,10-13)$ have a constant level through July (Fig. 6d). Lake 3 instead discharges on 16 July, and lake 6 discharges on both 10 and 15 of July (Fig. 6d). The water levels of lake 3 increase $0.6 \mathrm{~m}$ during $8-16$ July before draining, whereas lake 6 increases $0.5 \mathrm{~m}$ during $8-9$ July before draining the first time, and then gradually increases $4.2 \mathrm{~m}$ during 10-14 July before its second drainage. Soon thereafter, lake 3 drains $77700 \mathrm{~m}^{3}$ of water (Fig. 7e). Lake water from lake 3 discharged mainly through a complex mixture of englacial and supraglacial conduit on 16 July (Fig. 9). But, some of the water from lake 3 flowed through a surface channel to lake 4 . For example, the images in Figure 9 show exposed ice walls of an englacial conduit with some parts exposed on the surface due to erosion from the drainage of lake 3 . The exposed ice was also observed in a field survey.

\subsubsection{Drainage events in May and July 2019}

According to Landsat-8 (21 May 2019), Sentinel-2 (28 May 2019) and PlanetScope (9, 11, 12 July 2019) images (Supplementary Table 2), drainage in 2019 occurred at lakes 1, 4, 5, 7 and 8 during 21-28 May, and lakes 1, 4, 7 and 8 during 9-12 July. These drainage events resembled those in 2018 except that lakes 14 and 15 did not discharge. After the first drainage in May 2019, exposed ice was observed on the same route as that in May 2018. This finding indicates that the first drainage event followed the same route in both years. The second event had less drainage and the route was hard to discern. After the drainages in July, each lake discharged at later, but different, times. From both UAV and satellite data, we determined that lake 4 discharged again on 14-15 July, whereas lake 7 discharged again on 24-27 July.

\section{Discussion}

\subsection{Connecting to main or branch englacial conduits}

Seven lakes $(1,4,5,7,8,14,15)$ drained at the same time on 17 July 2018, indicating that they shared one or more englacial conduits despite being on different tributary glaciers. Five of them $(4,5,7,14,15)$ recharged after the drainage event, with three of them $(4,5,7)$ discharging again later, though at different times. The different times of discharge indicate that these three lakes no longer shared an englacial conduit after the earlier drainage event, suggesting that part of the englacial conduit system changed.

That the three lakes $(4,5,7)$ recharged and then discharged suggests that their englacial conduit had closed temporarily and then opened. These lakes discharged again within a few days. This suggests that the conduit may not have completely closed. Such temporary blockages may be due to either a collapse (external or internal), or to transported material (debris or ice). Fountain and Walder (1998) reported that englacial conduits develop vertically from crevasses, and then form complex branching networks by uniting with other englacial conduits. These englacial conduits are complex shapes such as curving and branching channels (Gulley and Benn, 2017; Gulley and others, 2009). Such a network consists of a main conduit to which branch conduits connect from various lakes. The discharge event of each lake after recharging may be due to an opening of a branch englacial conduit connecting to the main englacial conduit.

For the study site, we sketch such a network and time sequence in Figure 10. Consider first lake 5. Its first drainage on 8 July 2018 occurs when its branch englacial conduit connects to the main englacial conduit (Figs 10a, b). Although the englacial conduit is at the lake bottom (Fig. 7b), drainage had been impeded due to the deposition of ice and debris. Also, as it shares water with three other lakes $(4,7,8)$, the water level stabilizes until the multiple-drainage event on 17 July (Figs 6c, 10c). This event drains lakes $1,4,5,7,8,14$ and 15 when the main englacial conduit opens (Figs 10b, c). This opening may be due to an increase in water pressure, at least partly due to the release of water from lake 5, to water supplied to lake 4 from lake 3 on 16 July, and to an increase of meltwater on the glacier surface. Then, temporal closure of each branch englacial conduit by debris and ice deposits (Fig. 10d) causes lakes 4,5 and 7 to recharge. Subsequent discharging of these lakes then occurs due to branch conduits opening at different times as in Figs 10d, e. In this way, the branch englacial conduits allow small-scale drainage, whereas the opening of the main englacial conduit can cause large-scale drainage.

Based on these results, we group the development of lake basins and englacial conduits into several types in Figure 11. In 

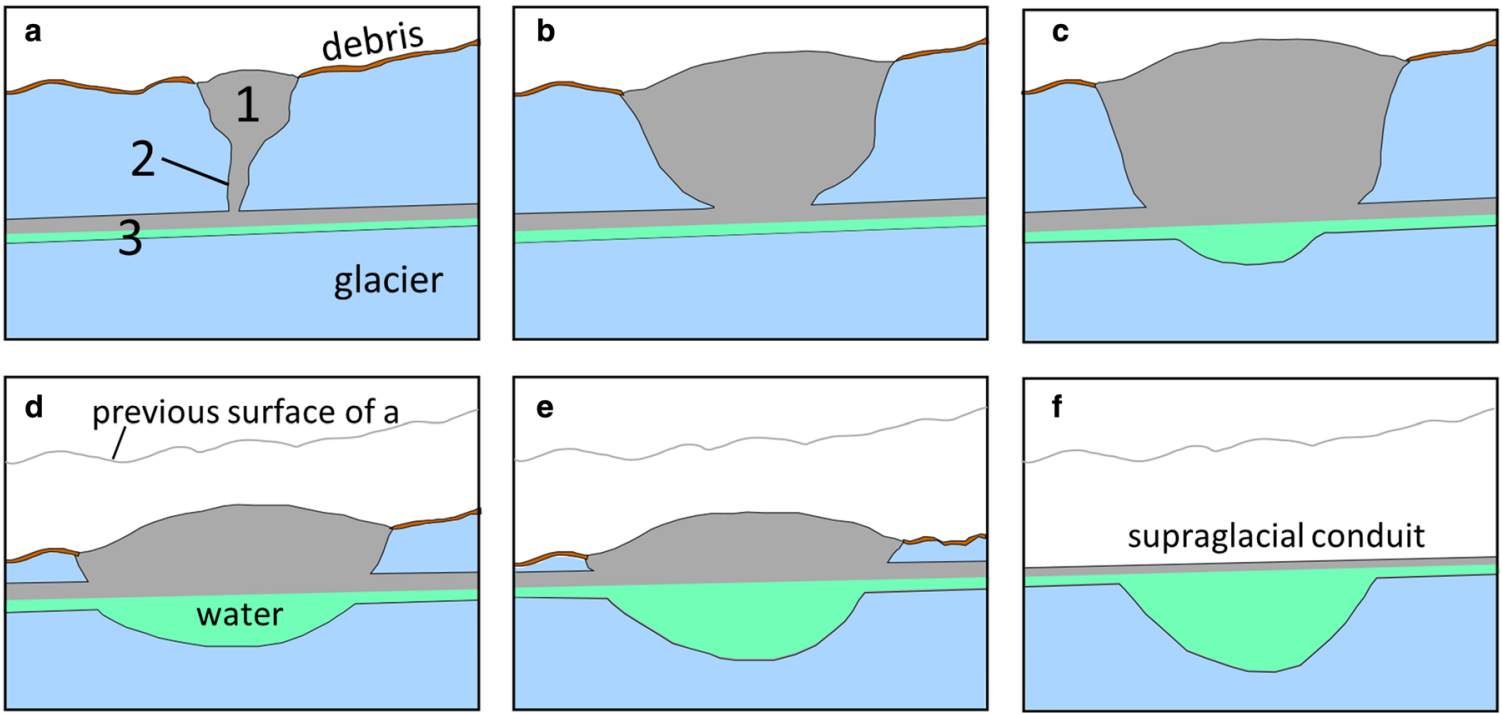

1: lake basin, 2: branch englacial conduit, 3: main englacial conduit a: vertical channel type, d,e: horizontal channel type

Fig. 11. Development process of lake basin. (a) Vertical channel type. Lake basin connects to the main englacial conduit through a branch englacial conduit. (b, c) Lake basin connects directly to the main englacial conduit due to ice melting. (d, e) Horizontal channel type. Lake basin and main englacial conduit become closer to the glacier surface due to glacier melting. (f) Supraglacial conduit. The englacial conduit becomes exposed on the glacier surface.

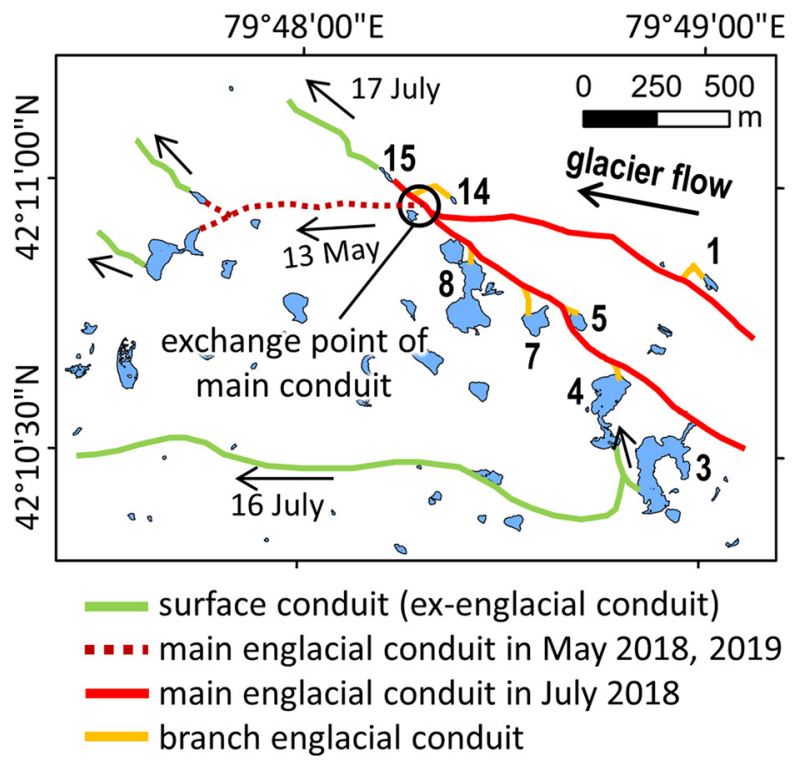

Fig. 12. Estimated locations of the main and branch englacial conduits 2018-2019. The circled exchange point of the channel shows the location where the main englacial conduit changed from May 2018 to July 2018.

Figure $11 \mathrm{a}$, the branch englacial conduit has developed a mainly vertical connection between the main englacial conduit and the lake basin. This 'vertical channel' type fits lake 5. The basin expands due to back-wasting, collapse of an ice wall or ice melting around the basin (Watson and others, 2017). For lakes 4 and 7 in 2019, we argue that the bottom of the basin connected to the main englacial conduit without a branch englacial conduit as sketched in Figs 11 b, c. Later, as the glacier surface ablates, the main englacial conduit approaches the surface (Figs 11d, e). Eventually, the main englacial conduit is exposed on the surface, becoming a supraglacial conduit as in Figure 11f. This situation applies to lake 15, which we call a 'horizontal channel' type. Lake 15 retained water after the simultaneous drainage event because its basin was connected to the main englacial conduit directly without a branch englacial channel.

A sudden recharge also suggests the presence of subsurface channels from other lakes. For example, in July 2017, after each of two drainages, the level of lake 1 increased 7.5 and $8.3 \mathrm{~m}$ over $1 \mathrm{~d}$. The sudden and large increase indicates that inflow occurred from one or more lakes discharging through an englacial network.

\subsection{Abandonment and reuse of englacial conduits}

Of the seven lakes that drained simultaneously $(1,4,5,7,8,14$, 15) on 17 July 2018, the first five of them also drained simultaneously 2 months earlier (13 May). Thus, the drainage route of the first five lakes did not pass through the last two lakes $(14,15)$ in May, yet did so in July (Figs 5,8 ). This indicates a change in the englacial conduit between May and July. Specifically, the five lakes $(1,4,5,7,8)$ and the two lakes $(14,15)$ did not connect through the main englacial conduit (Fig. 10f). But in July, the last two lakes connected to the first five through a former englacial channel that became exposed at the glacier surface.

In May and July 2019, four of the same five lakes $(1,4,7,8$, but not 5) drained simultaneously, similar to their drainage events in May and July 2018. This repeating behavior indicates that the englacial conduit in 2018 and 2019 had the same network connections. As lake 5 did not drain in July 2019, its branch englacial conduit probably did not connect to the main englacial conduit.

Based on this behavior, we propose the approximate location of conduits shown in Figure 12. The branch englacial conduits (orange) connect lakes or basins to a main englacial conduit (red). Part of the main englacial conduit changed between May and July 2018, as marked with a dotted red curve, and the main englacial conduit changed back again the next year in May 2019. These changes of main englacial conduit are consistent with the repeat cycles of abandonment and reuse reported by Benn and others $(2012,2017)$. In addition, we observed an englacial conduit that split into two channels (Fig. 7f; photo locations in Fig. 2a). Thus, englacial conduits may contain several routes and continually change channels. 

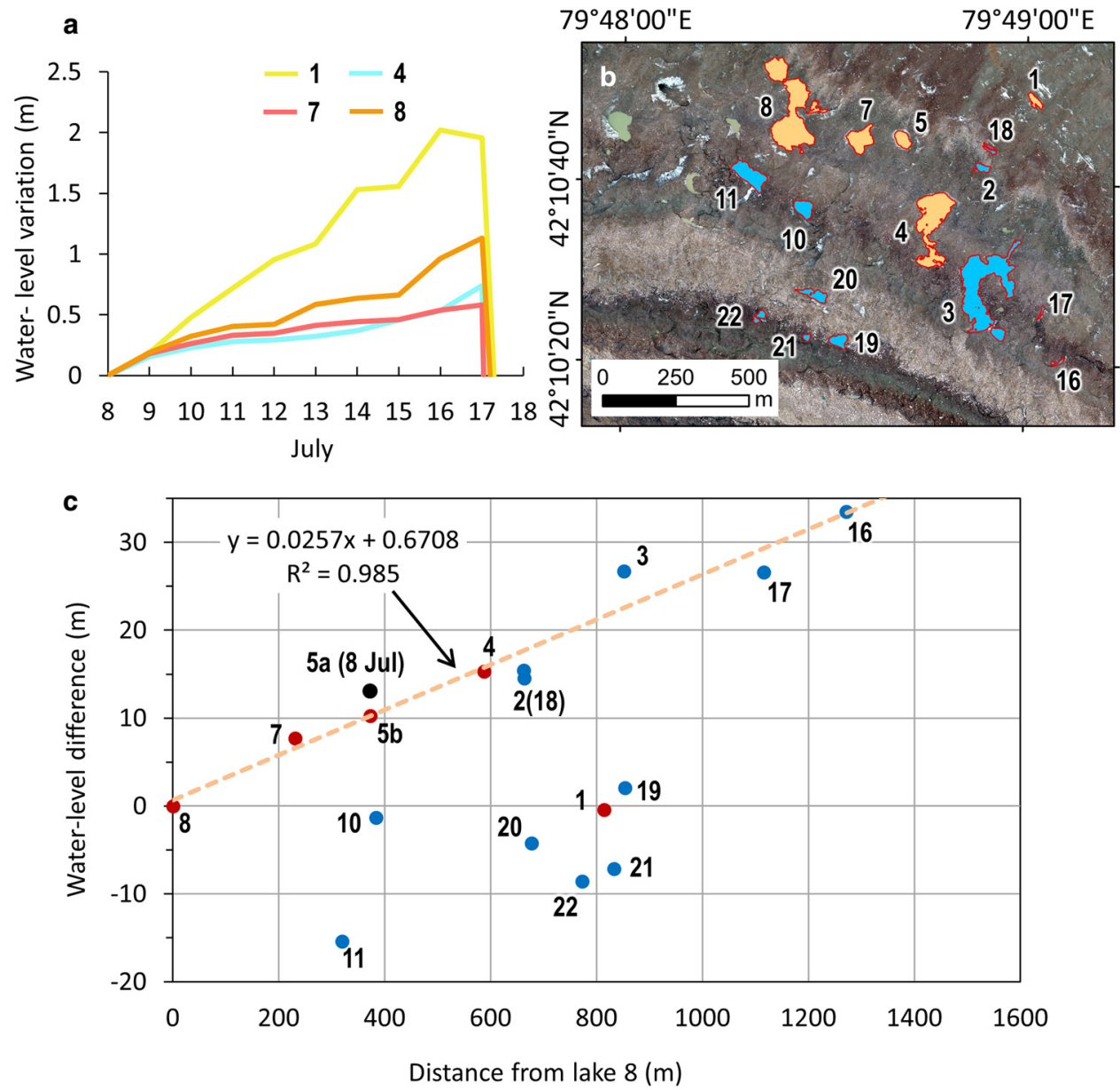

Fig. 13. Characteristics of supraglacial lakes before the simultaneous drainage event on 17 July 2018. (a) Water-level increases of lakes $1,4,7$ and 8 . (b) Locations of supraglacial lakes. Red-outlined lakes participated in the drainage event. Blue lakes are not related to the drainage event. Location is marked in Figure $2 \mathrm{~b}$. (c) Water-level differences for each lake, depending on distance to lake 8 . Red points $(1,4,5 b, 7,8)$ are lakes that drained simultaneously. The blue points $(2,3$, $10,11,16,17,18,19,20,21,22)$ are lakes unrelated to the drainage event. The black point $(5 a)$ is the water level of lake 5 before the first drainage on 8 July 2018, whereas 5b marks the water level before the second drainage on 17 July 2018.

\subsection{Phenomena of simultaneous drainage events}

The DSM and water-level loggers showed the water level of several lakes to increase gradually before drainage, consistent with previous studies (Miles and others, 2017b; Narama and others, 2017). For example, Figure 13a shows the increase in water level of lakes $1,4,7$ and 8 , just before their simultaneous discharge on 17 July 2018. Three of these lakes $(4,7,8)$ increase at nearly the same relatively low rate. If they were connected to the same englacial conduit and main englacial conduit closed completely, then their water levels should become the same, behaving like communicating vessels. However, their water levels have different elevations before drainage (Fig. 6c). Having the same gradual increases of water level at different elevation indicates that the opening of an englacial conduit may be caused by an increase in water pressure in the conduit with the increase in water level being due to an inflow of meltwater. Thus, the behavior suggests that they were connected to the same englacial conduits, but as their levels differed, the main conduit might not have closed completely.

In addition, we examined the relations between the water levels for all of the monitored lakes near lake 8 (Fig. 13b). In Figure 13c, we plot the horizontal distance from lake 8 versus the difference in lake-surface elevation. Lake 8 is the reference here because it was the lowest elevation lake in the group that drained simultaneously on 17 July 2018. As recent studies found that the hydraulic potential between supraglacial lakes is governed by the pressure gradient (Benn and Evans, 2010; How and others, 2017; Ravier and Buoncristiani, 2018), we similarly fit a hydraulic gradient line between the lakes that drained. Four of these lakes $(4,5 b$, 7,8 ) lie on the same hydraulic gradient line (orange dashed line) in Figure $13 c$, suggesting that if the main englacial conduit had not been completely closed, they would share water through the same englacial conduit. Most other lakes $(10,11,19-22)$ are well below the line. Lakes 3 and $5 \mathrm{a}$ are slightly above the hydraulic gradient line, suggesting that they are not fully connected to the main englacial conduit. However, after the first drainage on 8 July, the lake level for lake 5 moves down to the line (5b) as sketched in Figures 10a, b, presumably because the englacial conduit became shared by four lakes $(4,5,7,8)$. Although lake 1 also drained in the drainage event $(4,5,7,8)$ on 17 July 2018 , it does not lie on the hydraulic gradient line. This suggests that it drained through a different englacial conduit (Fig. 10c). Lake 1 also differs from 4, 7, 8 in having a different increase rate of water level (Fig. 13a), and in 2017, its water-level variations differed from that of the other four lakes. We also confirmed the same situation before and after lake 3 drained (Fig. 9). Lakes 20, 23, 25, 28 and 32 existed before drainage from lake 3 on 16 July 2018 (Supplementary Fig. 1a). These lakes lie on the same hydraulic gradient line (Supplementary Fig. 1b). We found that after lake 3 drained, these lakes developed on the same englacial conduit (Fig. 9b).

The three lakes with nearly the same rate in water-level increase $(4,7,8)$ all fall on the same line in Figure 13c. As they 
also discharged simultaneously, they likely shared the same main englacial conduit. If this correlation is general, then lakes with the same rate of increase, and that lie along a hydraulic gradient line, may be more likely to share the same main englacial conduit. And if they do share the same conduit, then they would experience a simultaneous large-scale drainage event if their main englacial conduit opened. If so, then by using satellite data to monitor the variations of area and water levels of supraglacial lakes, one may confirm such a pattern of water storage and drainage events. In the Tien Shan, the total area of many supraglacial lakes has increased, due to glacier shrinkage under climatic warming (Wang and others, 2013). We found here that the simultaneous drainage event that can produce large-scale flooding occurs from multiple supraglacial lakes on a debris-covered glacier. The larger the network connecting the lakes, the greater the potential amount of water that may discharge. In this way, monitoring the water levels of supraglacial lakes on a debris-covered glacier may help us predict the occurrence of some large-scale drainage events.

\section{Conclusions}

We used DSMs and ortho-images derived from an uncrewed aerial vehicle (UAV) to investigate daily water-level variations of supraglacial lakes on a debris-covered glacier in 2017, 2018 and 2019. Although the UAV has a limited range and survey period, and is dependent on the weather, the daily DSMs and ortho-images were very effective in enabling the understanding of the details of water-level variations on the southern Inylcheck Glacier. We observed several simultaneous drainage events and argued that for such an event to occur, each lake should be connected to the same main englacial conduit via a branch englacial conduit. Moreover, the larger the network connecting the lakes, the greater the water volume that may be discharged simultaneously. For the drainage events occurring from only one lake, the event indicated an opening of a branch englacial conduit to the main englacial conduit. In addition, the drainage routes of englacial conduits changed over a timescale of months. Debris and ice deposits sometimes closed one branch, leaving other ones open. Before a simultaneous drainage event, the water levels of the lakes tended to increase gradually. If several lakes shared the same main englacial channel and were on the same hydraulic gradient line, then they also showed similar rates of increase in water level. Therefore, by monitoring water levels, one might be able to determine which lakes share the same englacial channel.

These results may help us to predict possible large-scale drainage events that may lead to floods. But to apply the results to a given region, we need to monitor the region using daily, highresolution satellite images and use the data to determine if the supraglacial lakes are likely connected via a main englacial conduit.

Supplementary material. The supplementary material for this article can be found at https://doi.org/10.1017/jog.2021.77.

Acknowledgements. We thank B. Moldobekov, R. Usubaliev, A. Osmonov, E. Azisov R. Kenzhebaev of the Central-Asian Institute for Applied Geosciences (CAIAG), Ak-Say Travel, Mizunuma of NSi Co. Ltd., T. Matsumoto, R. Nishii, Y. Mori, H. Takadama, S. Okuyama, M. Yamamoto and N. Honma of Niigata University. We also thank the editor J. Shea, H. Jiskoot and two anonymous reviewers for valuable comments that helped to improve the paper. This study was supported by Grant-in-Aid for Scientific Research (B) $16 \mathrm{H} 05642$ and $19 \mathrm{H} 01372$ of the Ministry of Education, Culture, Sports, Science and Technology (MEXT), and the Sasakawa Scientific Research Grant from The Japan Science Society, and Inoue Field Science Research Fund from The Japanese Society of Snow and Ice.

\section{References}

Bartholomaus TC, Anderson RS and Anderson SP (2011) Growth and collapse of the distributed subglacial hydrologic system of Kennicott Glacier, Alaska, USA, and its effects on basal motion. Journal of Glaciology 57 (206), 985-1002. doi: 10.3189/002214311798843269

Benn DI and 9 others (2012) Response of debris-covered glaciers in the Mount Everest region to recent warming, and implications for outburst flood hazards. Earth Science Reviews 114, 156-174. doi: 10.1016/j.earscirev. 2012.03.008

Benn DI and 5 others (2017) Structure and evolution of the drainage system of a Himalayan debris-covered glacier, and its relationship with patterns of mass loss. The Cryosphere 11, 2247-2264. doi: 10.5194/tc-11-2247-2017

Benn DI and Evans DJA (2010) Glaciers and Glaciation, 2nd Edn. London: Hodder education.

Fountain AG and Walder JS (1998) Water flow through temperate glaciers. Reviews of Geophysics 36(3), 299-328.

Gulley J and Benn DI (2017) Structural control of englacial drainage systems in Himalayan debris-covered glaciers. Journal of Glaciology 53(182), 399412. doi: 10.3189/002214307783258378

Gulley JD, Benn DI, Müller D and Luckman A (2009) A cut-and-closure origin for englacial conduits in uncrevassed regions of polythermal glaciers. Journal of Glaciology 55(189), 66-80. doi: 10.3189/002214309788608930

How P and 9 others (2017) Rapidly changing subglacial hydrological pathways at a tidewater glacier revealed through simultaneous observations of water pressure, supraglacial lakes, meltwater plumes and surface velocities. The Cryosphere 11, 2691-2710. doi: 10.5194/tc-11-2691-2017

Immerzeel WW and 6 others (2014) High-resolution monitoring of Himalayan glacier dynamics using unmanned aerial vehicles. Remote Sensing of Environment 150, 93-103. doi: 10.1016/j.rse.2014.04.025

Komori J, Koike T, Yamanokuchi T and Tshering P (2012) Glacial lake outburst events in the Bhutan Himalayas. Global Environmental Research 16, 59-70.

Liu Q, Mayer C and Liu S (2015) Distribution and interannual variability of supraglacial lakes on debris-covered glaciers in the Khan Tengri-Tomur Mountains, Central Asia. Environmental Research Letters 10, 4545-4584. doi: 10.1088/1748-9326/10/1/014014

Miles ES, Willis IC, Arnold NS, Steiner J and Pellicciotti F (2017a) Spatial, seasonal and interannual variability of supraglacial ponds in the Langtang Valley of Nepal, 1999-2013. Journal of Glaciology 63(237), 88-105. doi: 10.1017/jog.2016.120

Miles ES and 6 others (2017b) Pond dynamics and supraglacial-englacial connectivity on debris-covered Lirung Glacier, Nepal. Frontiers in Earth Science 69, 1-19. doi: 10.3389/feart.2017.00069

Miles ES and 8 others (2018a) Glacial and geomorphic effects of a supraglacial lake drainage and outburst event, Everest region, Nepal Himalaya. The Cryosphere 12, 3891-3905. doi: 10.5194/tc-12-3891-2018

Miles ES and 5 others (2018b) Surface pond energy absorption across four Himalayan glaciers accounts for $1 / 8$ of total catchment ice loss. Geophysical Research Letters 45(19), 10464-10473. doi: 10.1029/ 2018GL079678, 10464-10473

Narama C and 6 others (2017) Seasonal drainage of supraglacial lakes on debris-covered glaciers in the Tien Shan Mountains, Central Asia. Geomorphology 286, 133-142. doi: 10.1016/j.geomorph.2017.03.002

Narama C and 7 others (2018) Large drainages from short-lived glacial lakes in the Teskey Range, Tien Shan Mountains, Central Asia. Natural Hazards and Earth System Sciences 18, 983-995. doi: 10.5194/nhess-18-983-2018

Nobakht M, Motagh M, Wetzel H, Roessner S and Kaufmann H (2014) The Inylchek Glacier in Kyrgyzstan, Central Asia: insight on surface kinematics from optical remote sensing imagery. Remote Sensing 6, 841-856. doi: 10. 3390/rs6010841

Osmonov A, Bolch T, Xi C, Kurban A and Guo W (2013) Glacier characteristics and changes in the Sary-Jaz River Basin (Central Tien Shan, Kyrgyzstan) 1990-2010. Remote Sensing Letters 4, 725-734. doi: 10.1080/ 2150704X.2013.789146

Pieczonka T, Bolch T, Kröhnert M, Peters J and Liu S (2018) Glacier branch lines and glacier ice thickness estimation for debris-covered glaciers in the Central Tien Shan. Journal of Glaciology 64(247), 835-849. doi: 10.1017/jog. 2018.75

Piermattei L and 6 others (2016) Suitability of ground-based SfM-MVS for monitoring glacial and periglacial processes. Earth Surface Dynamics 4, 425-443. doi: 10.5194/esurf-4-425-2016 
Piermattei L, Carturan L and Guarnieri A (2015) Use of terrestrial photogrammetry based on structure-from-motion for mass balance estimation of a small glacier in the Italian Alps. Earth Surface Processes and Landforms 40, 1791-1802. doi: 10.1002/esp.3756

Ravier E and Buoncristiani JF (2018) Glaciohydrogeology. In Menzies J and van der Meer JJM (eds), Past Glacial Environments. Amsterdam: Elsevier, 431-466.

Reyers M, Pinto JG and Paeth H (2013) Statistical-dynamical downscaling of present day and future precipitation regimes in the Aksu River Catchment in Central Asia. Global and Planetary Change 107, 36-49. doi: 10.1016/j. gloplacha.2013.04.003

Reynolds J (2000) On the formation of supraglacial lakes on debris-covered glaciers. In Nakawo M, Raymond CF and Fountain A eds. Debris-Covered Glaciers. IAHS-AISH publication Wallingford: IAHS, 153-161.

Richardson SD, Quincey DJ and Nasab N (2009) The 2008 glacier outburst floods from Ghulkin Glacier, Karakoram, Pakistan. Glacier Hazards Workshop. Universität für Bodenkultur, BOKU, Vienna.

Rounce DR, Byers AC, Byers EA and McKinney DC (2017) Brief communication: observations of a glacier outburst flood from Lhotse Glacier, Everest area, Nepal. The Cryosphere 11, 443-449. doi: 10.5194/tc-11-443-2017

Sakai A (2001) Ablation processes of debris-covered glaciers. Journal of the Japanese Society of Snow and Ice 63, 191-200, (in Japanese).

Sakai A and 5 others (2015) Climate regime of Asian glaciers revealed by GAMDAM glacier inventory. The Cryosphere 9, 865-880. doi: 10.5194/ tc-9-865-2015
Shangguan DH and 5 others (2015) Mass changes of Southern and Northern Inylchek Glacier, Central Tian Shan, Kyrgyzstan, during 1975 and 2007 derived from remote sensing data. The Cryosphere 9, 703-717. doi: 10.5194/ tc-9-703-2015

Takeuchi N, Sakai A, Shiro K, Fujita K and Nakawo M (2012) Variation in suspended sediment concentration of supraglacial lakes on debris-covered area of the Lirung Glacier in the Nepal Himalayas. Global Environmental Research 16, 95-104.

Thompson SS, Benn DI, Dennis K and Luckman A (2012) A rapidly growing moraine-dammed glacial lake on Ngozumpa Glacier, Nepal. Geomorphology 145-146, 1-11. doi: 10.1016/j.geomorph.2011.08.015

Wang X and 6 others (2013) Changes of glacial lakes and implications in Tian Shan, Central Asia, based on remote sensing data from 1990 to 2010. Environmental Research Letters 8, 044052. doi: 10.1088/1748-9326/8/4/ 044052

Watson CS and 5 others (2017) Quantifying ice cliff evolution with multitemporal point clouds on the debris-covered Khumbu Glacier, Nepal. Journal of Glaciology 63(241), 823-837. doi: 10.1017/jog.2017.47

Watson CS, Quincey D, Carrivick J and Smith M (2016) The dynamics of supraglacial ponds in the Everest region, central Himalaya. Global and Planetary Change 142, 14-27. doi: 10.1016/j.gloplacha.2016.04.008

Yamanokuchi T, Tadono T, Komori J, Kawamoto $\mathbf{S}$ and Tomiyama N (2011) Temporal monitoring of supraglacial lakes on Tshojo Glacier at Bhutan. IEEE International Geoscience and Remote Sensing Symposium. Vancouver, Canada Paper No. 3830. 